\title{
Designing a line of Indo-western dresses using peacock motifs
}

\author{
A. GUPTA AND K. BRAR
}

Received: 22.09.2014; Revised: 13.11.2014; Accepted: 26.11 .2014

See end of the paper for authors' affiliations

\section{A. GUPTA}

Department of Apparel and

Textile Science, College of Home

Science, Punjab Agricultural

University, LUDHIANA (PUNJAB)

INDIA

Email: ancha1214@gmail.com
ABSTRACT : A line of Indo-western dresses on peacock theme was designed using twenty peacock motifs comprising of top ten motifs from each category, i.e. realistic and stylized motifs, adjudged best by a panel of ten judges. For designing Indo-western dresses, motif $R_{9}$ was most preferred (mean scores 4.80 ) by the judges followed by motif $R_{20}$ which obtained second rank with mean scores 4.40 . Among the stylized motifs, $S_{20}$ motif was most preferred (mean scores 5.60) followed by motif $S_{17}$ which obtained second rank with mean scores 5.50. Twenty innovative designs of Indo-western dresses were developed in Corel Draw X5 by using ten most preferred peacock motifs which were highly appreciated by the college-going girls.

KEY WORDS: Indo-western dresses, Peacock motifs

— HOW TO CITE THIS PAPER : Gupta, A. and Brar, K. (2014). Designing a line of Indo-western dresses using peacock motifs. Asian J. Home Sci., 9 (2) : 561-567. 